\title{
Internally Displaced and Refugee Students in Cameroon: Some Pedagogical Proposals
}

\author{
Gilbert Tagne Safotso ${ }^{1}$ \\ ${ }^{1}$ Department of Foreign Applied Languages, University of Dschang, Cameroon \\ Correspondence: Gilbert Tagne Safotso, Department of Foreign Applied Languages, University of Dschang, \\ Cameroon, P.O. Box 282 Dschang, Cameroon.
}

Received: September 11, 2020

Accepted: October 19, 2020

Online Published: October 29, 2020

doi: 10.5539/elt.v13n11p140

URL: https://doi.org/10.5539/elt.v13n11p140

\begin{abstract}
For some six years now, Cameroon has been experiencing unprecedented war disturbances. Since 2014, its three northern regions have been undergoing the hardship of Boko Haram ruthless attacks leading to thousands of internally and externally displaced families and hundreds of schools closed down. The Minawao Refugees Camp near Mokolo with over 60000 inhabitants, mostly Nigerians, somewhat testifies to the gravity of the situation. A similar Camp is located in Gado-Badzere near Garoua-Boulaï in the East Region, populated by Central African Republic refugees. The Zamay Camp is occupied by internally displaced Cameroonian families of the far North Region. The troubles in the South and North-West which started in 2016 considerably increased the number of internally displaced Cameroonians in the neighbouring French-speaking zones of the West and the Littoral Regions. In the refugee camps or in the invaded zones, class sizes have simply become unmanageable with many of them rising from simple to double or triple. Teachers who were trained to teach around 50 to 100 students per class have suddenly found themselves managing 150 - 200 learners in some classes without any preparation. Among the learners of the same class, some have abandoned school for two to three years. Those learners thus need a special pedagogy. This paper aims to propose some pedagogical solutions to such classes.
\end{abstract}

Keywords: internally displaced, refugees, learners, teaching, pedagogy, strategies, material

\section{Introduction}

The problem of refugees and displaced populations across the world is not new. Even the Holy Bible abounds in examples: Exodus, Psalm 137, Ezekiel 36, etc. Only the periods when it occurs, the treatment of the people concerned and the various ways of solving their problems differ. During the 20th and early 21 st century, the situation has somewhat worsened with the First and Second Wold Wars, which forced millions of people to flee from their homes. The many current crises experienced here and there across the globe also quite complicate the situation. Before and shortly after the independence of East Cameroon (French Cameroon) in 1960, the country already experienced some disturbances which led to internally displaced populations. They were grouped in a kind of rudimentary concentration camps for safety from the rebels who were dissatisfied with the way in which the country was governed. Those camps where mostly found in the Bassa and Bamileke regions where they attacked civilians and government institutions on a daily basis. Some of those camps have today grown into small towns as some villagers never went back to their homes and villages.

The two crises that Cameroon is enduring now, i. e. Boko Haram in the northern regions and the secessionist movements in the South and North West are more serious as they concern five of the ten regions of the country. Given that women and children are generally hard hit by those troubles, this paper aims to propose some pedagogical solution for children whose education is hampered by the two crises. It first reviews some literature on the issue, presents some facts on the field and the situation in the classroom before proposing some solutions. This study contributes to the existing body of knowledge on displaced learners which so far has mostly been concentrating on the case of refugee students.

\section{Review of Some Literature}

A number of studies have concentrated on refugee students' educational difficulties and how to handle them (Candillon, 2003; Carpenter, 2006; Roxas, 2011; Windle \& Miller, 2012; Dryden-Peterson, 2015). Dryden-Peterson observes that "gaps in understanding about resettlement histories can negatively affect refugee 
children's sense of belonging and relationship with teachers and peers, as well as the provision of adequate and psychosocial services" (p.1). Taking the case of the USA, she notes that the prior schooling experiences of refugees have considerable implications for post-settlement. Many refugee students experience frequent disruptions and limited access to schooling (Dryden-Peterson, 2015, p.1). Candillon (2003) gives some advice on teaching large groups such as exploring students' prior knowledge of the subject, giving handouts with partially completed diagrams and list for students to complete after the lecture, etc. Carpenter (2006) proposes some effective methods for large classes (in the USA): (1) assessment of teaching methods, (2) assessment of the course, preferences for class size, (3)and perception of some teaching methods. Windle \& Miller (2012, p. 320) remark that "creating a classroom context in which students' cultural knowledge is expressed, shared and affirmed is motivating, but also help to make language concepts more meaningful".

Austin and Sciarra (2016) suggest how to deal with difficult students and disruptive behaviour in the classroom. They advised that all teachers must acquire the skills and dispositions necessary to effectively teach students via a wide variety of needs. Teacher preparation programs and schools must find ways and means to ensure that pre-service and novice teachers are prepared to address the increasingly diverse needs of all students assigned to their classrooms. Citing Cavin (1998, p. 9), they point out that teachers must be encouraged to remember that all the kids with all of their problems, their criminal records, their probation officers, their idiosyncrasies, their unsolvable characteristics, and their strange families are still kids. Cerna (2019, p. 51-53) recommends some integration models and practice in handling refugee education in OECD (Organization for Economic Co-operation and Development) member countries. Among others, she proposes to consider refugee integration in education through a holistic model; provide flexible learning options, pathways and transition for older students; offer specific teacher training and professional development to support the needs of refugee students; provide a supportive learning environment to them; create opportunities for social interactions between refugees and other students, and support their well-being, including mental health.

\section{Facts on the Field}

In the Far North Region of Cameroon, the NRC (Norwegian Refugee Council) Report 2019 citing UNICEF sources indicates that Boko Haram attacks, which have never stopped since 2014, led to 144 schools closed down in 2015 and thousands of families displaced. During that year, 36.000 children were left without education. In 2019, 92 primary and nursery schools were still closed and 23,000 school-aged children were out of school. In the North and South West regions, UNHCR (United Nations High Commission for Refugees) Report 2019 signals that in 2016 when the crisis started there were 595,935 refugees. In 2017, the number grew up to 598,578 people, and in 2018 they were 1,124,620, i.e. an increase of $88 \%$. UNICEF reports that, in 2019, in the two besieged regions, more than 855,000 children remained out of school. $90 \%$ of public primary schools, i.e. more than 4,100 schools and $77 \%$ of public secondary schools ( 744 schools) were closed or non operational. Almost 150,000 school-aged children have been displaced from their homes.

In the Minawao Camp near Mokolo in the Far North Region, there are presently 60,000 Nigerians. As a solution to their children's education, the Cameroonian government in 2013 created a secondary school for them near the camp. In the academic year 2019-2020, statistics from that school indicated that there were 547 learners registered, mostly taught by Cameroonian teachers who know nothing of the Nigerian educational system. The children are taught using the Cameroonian programmes. In the Garoua-Boulaï (Gado-Badzere Village) camp in the East Region, in 2017, there were some 260,000 Central African Republic nationals who escaped civil war in their country (UNHCR Report, 2017). The figures given here are just indicative as there are tens of thousands more people sleeping in open air or hosted by relatives. Concerning the internally displaced Cameroonians, 437,000 live in the Zamay Camp near Mokolo. Still in 2017, there were an estimated 200,000 displaced Cameroonians by violence or insecurity in the Far North Region, a situation which has not changed much as Boko Haram continues to loot, kill and burn down several villages in the region. So, actually, the number of internally displaced Cameroonians nationwide is quite alarming. Although it is beyond the scope of this study, it is also important to mention that Cross River and Tarlaba States in Nigeria are presently home to some 17, 000 Cameroonian refugees whose children have enormous educational difficulties.

\section{Situation in the Classrooms: The Case of the West Region}

Statistics from the Regional Delegation of Secondary Education for the West Region, in the academic years 2018-2019 and 2019-2020 respectively, signal 4,756 and 16,308 displaced students from the North and South West Regions in the various schools of the region as summarized in the following table. 
Table 1. Distribution of Displaced students from the North and South West Region in the various secondary schools of the West Region

\begin{tabular}{llll}
\hline $\begin{array}{l}\text { Administrative } \\
\text { Division }\end{array}$ & $\begin{array}{l}\text { Number of displaced } \\
\text { Students in 2018-2019 }\end{array}$ & $\begin{array}{l}\text { Number of displaced students } \\
\text { in 2019-2020 }\end{array}$ & Increase rate \\
\hline Bamboutos & 457 & 3,372 & $88.07 \%$ \\
Haut-Nkam & 253 & 451 & $64.07 \%$ \\
Hauts-Plateaux & 85 & 272 & $76.13 \%$ \\
Koung-Khi & 93 & 328 & $77.81 \%$ \\
Menoua & 1,170 & 4,255 & $78.68 \%$ \\
Mifi & 1,231 & 3,978 & $76.37 \%$ \\
Ndé & 286 & 482 & $62.77 \%$ \\
Noun & 1,181 & 3,171 & $62.76 \%$ \\
Total & $\mathbf{4 , 7 5 6}$ & $\mathbf{1 6 , 3 0 8}$ & $\mathbf{7 7 . 4 3 \%}$ \\
\hline
\end{tabular}

From the table it can be remarked that the total number of displaced students in the various secondary schools of the West Region from 2018 to 2020 has considerably increased, rising from 4,756 to 16,308 children (77.43\%). Given that the host schools and teachers were not prepared to receive such exceeding number of learners, the situation poses serious pedagogical problems. Table 2 below shows the increase rate of students in the Anglophone section of GBHS (Government Bilingual High School) Dschang.

Table 2. Increase rate of Anglophone learners in GBHS Dschang from 2015 to 2020

\begin{tabular}{lllll}
\hline Academic year & Francophone section & Increase rate & Anglophone section & Increase rate \\
\hline $2015-2016$ & 2,410 & - & 1,272 & - \\
$2016-2017$ & 2,313 (-97 students) & $-4.19 \%$ & $1,291(+19$ students $)$ & $1.48 \%$ \\
$2017-2018$ & 2,350 (+37 students) & $1.58 \%$ & $1,617(+326$ students $)$ & $20.17 \%$ \\
$2018-2019$ & $2,295(-55$ students $)$ & $-2.35 \%$ & $2,132(+515$ students $)$ & $24.15 \%$ \\
$2019-2020$ & $2,095(-200$ students $)$ & $-8.71 \%$ & $2,078(-54$ students $)$ & $-2.3 \%$ \\
\hline
\end{tabular}

From the table, it comes out that, in the Anglophone section of GBHS Dschang, the learners' number has steadily been on the increase since the academic year 2016-2017, rising from $1.48 \%$ to $24.15 \%$ in $2018-2019$. That period corresponds to the beginning and the peak of the crisis in the North/South West Regions. The slight drop of $-23 \%$ in 2019-2020 may be due to the fact that all the run away students from those regions were already in other francophone regions of the country or in Nigeria. It could also be explained that some of the learners who had been in that school for three years had already graduated by 2019-2020. During the same time (2016-2020), it is rather the reverse trend that is observed in the francophone section. Students' number has been declining from $-2.35 \%$ to $-8.71 \%$. That drop in French-speaking learners' number can be explained by the fact that all school principals of the francophone regions were instructed to give priority to displaced students. To solve the problem of high demand of Anglophone learners soliciting places in francophone regions, some purely francophone system schools (public and private) were also hastily transformed into bilingual ones. Collège Bilingue la Renaissance (Dschang), formerly known as Collège la Renaissance (Dschang) is an example of those institutions. The following table provides the Anglophone section learners' increase rate of that institution.

Table 3. Increase rate of Anglophone learners in Collège Bilingue la Renaissance, Dschang

\begin{tabular}{lllll}
\hline Academic year & Francophone section & Increase rate & Anglophone section & Increase rate \\
\hline $2018-2019$ & 106 & - & 341 & (creation) \\
$2019-2020$ & $224(+118$ students $)$ & $56.26 \%$ & $906(+565$ students $)$ & $62.36 \%$
\end{tabular}

As can be noted in the table, that school was transformed into a bilingual one in the academic year 2018-2019, in the heart of the secessionists' crisis. With only 341 students at its transformation (creation) in 2018, the number rapidly rose to 909 students in 2019-2020, i.e. an increase rate of $62.36 \%$. Unlike the francophone section of GBHS of the same town, the students' intake in that section here has also been increasing (56.26\%). To some extent, that sudden increase can be attributed to the Anglophone crisis as in the North/South West regions of Cameroon there were also a number of bilingual schools which had francophone sections. 
At tertiary level, the lack of statistics does not permit to give an increase rate of internally displaced students in the higher institutions of the West Region. As already mentioned, it is one of the neighbouring regions of the North/South West Regions in crisis. Nevertheless, during the academic years 2018-2019 and 2019-2020, a considerable number of Anglophone students registered at the University of Dschang. Some of them did it very late (around January), because they had been expecting the situation in their regions to calm down. For instance, in 2018-2019, in Level One Commonwealth Studies the class which started with about 80 students ended with 190 learners. Level Three began with 72 learners and ended with 148 students.

\section{Pedagogical Problems of Internally Displaced and Refugee Students in Cameroon}

All the political and economical considerations put aside, internally displaced and refugee students in Cameroon face almost the same psychological and pedagogical problems. They include trauma of war, insecurity, famine, homesickness, lack of learning materials, breaks and interruptions in their learning process, non adapted and overcrowded classes, unprepared teachers, inadequate teaching materials, culture shock, unfamiliar environment, hostility or reluctance of the host community, etc.

\section{Some Proposals}

To adequately handle their pedagogical problems, there are a number of things teachers and school administration should understand and do. Some of those issues are enumerated and explained below. The proposals made here mainly concern secondary and basic education as higher education is a different reality.

\subsection{Teacher's Responsibility}

1. Teachers should try to understand the trauma their learners have gone through. Mentally hard hit students are very different from those who live in normal situation. They have witnessed horrible scenes and are haunted by them even when they are attending classes. Some have watched the slaughtering of their parents and other kinds of brutality.

2. The instructors should provide occasions to learners to tell their stories to avoid nervousness. By telling those stories, they will somewhat feel relieved. It will also help other learners better understand them and why they behave in a certain way.

3. Teachers should be sensitive to their past experiences and tolerant towards their behaviour. Doing so means paying attention to their little actions by kindly asking them why they do certain things differently from their classmates. This will instil self-confidence in them and help them open up to their teachers and peers.

4. Since some learners do not have any parent, teachers should be a kind of substitute for them by being tender and living. They can also offer from time to time (to the most need) some little gifts. They will feel loved respected and will take their studies seriously.

5. As those learners (case of refugee students) come from a different educational system, teachers should learn something about it, and not simply impose their local programmes on them. For example, in Government High School Mimawao (a school for Nigerian refugee students) as well as in primary schools in the refugee camp near Garoua-Boulaï, the majority of teachers are Cameroonians who know very little about the Nigerian and Central African Republic educational systems. They teach learners with Cameroonian programmes. Not knowing anything about their learners' former education system can be quite problematic as many Nigerian or Central African Republic children ran into Cameroon after attending school in their various countries for years.

6. Whenever possible, catch-up classes should be organised for some learners to somewhat put them at the same level as their classmates. This is because when internally displaced or refugee students are grouped in various classes, each of them has their own past education history which does not always match with the new system expectations.

\subsection{School Administration Responsibility}

In this situation, the school administration's responsibility like that of teachers is very heavy. Teachers and administration should cooperate to make the task successful. Therefore, school administration should supply the necessary means to give free learning materials (books, exercise books, pens pencils) and handouts to students. In Africa, very often, NGO and the government provide this, but it is at times mismanaged or embezzled.

Another important solution would be to organise frequent discussion sessions with learners and their parents to know their real needs and how children take their studies when they go back home. Most of the time those children live in tiny tents with many other family members. So, if parents are not concerned with their education back home, the lack of space may constrain them to content just with what they heard at school. Special catch-up programmes should be prepared for learners who have been out of school for some years. Indeed, some children 
come back to school after have been in the bush or have been wandering for a number of years. The best solution for that type of learner may be a special catch-up programme prepared by school administration after assessing their needs.

Other possible pedagogical solutions may include organising special training seminars for teachers handling those groups and creating support groups composed of teachers and some well balanced learners. Those special training seminars will acquaint the instructors with the type of learners they have to handle, and will familiarise them with the educational system where their learners come from (for the case of refugee students). In extreme cases, children who cannot still cope up with education should be grouped in special classes where they can learn little trades such as sewing, carpentry, mechanics, crafts, etc that will rapidly help them earn their living. At macro level, the government should ensure that all schools which host displaced or refugee students have a canteen where they can feed for free.

\section{Conclusion}

In short, internally displaced and refugee learners are very different from ordinary ones. They may have undergone the trauma of armed conflicts, slept in bushes and open air for days and years, trekked on long distances with their bundles, and have endured all kinds of sufferings. They therefore need a special pedagogy to cope with education again. This limitation of this study is that it did not go beyond the Cameroonian boundaries to assess the situation of Cameroonian refugee learners living in Nigeria.

\section{Acknowledgements}

I wish to thank the following people for supplying very useful information for the completion of this paper: The Regional Delegate of Secondary Education for the West Region for the statistics on the number of internally displaced students in the various schools of the region. Special thanks to Ms Askiya Ogza, English language teacher at Minawao Government High School who supplied important information on her school and the refugee camp. I am equally very grateful to Mrs Noami Temezeu of Government Bilingual High School Dschang and Mr. Kengne Jean Pierre of Collège Bilingue la Renaissance Dschang, for providing important information on their various schools.

\section{References}

Austin, \& Sciara. (2016). Difficult students and disruptive behaviour in the classroom: Teacher responses that work. New York: Norton \& Company.

Candillon, P. (2003). Teaching Large Groups. BMJ, 326(382), 437-440. https://doi.org/10.1136/bmj.326.7386.437

Carpenter, J. M. (2006). Effective Teaching Methods for Large Classes. Journal of Family \&Consumer Sciences Education, 24(2), 13-23.

Cerna, L. (2019). Refugee Education: Integration Models and Practices in OECD Countries. OECD Education Working Papers, 203, 1-73.

Dryden-Peterson, S. (2015). The Education Experience of Refugee Children in Countries of First Asylum. Washington, DC: Migration Policy Institute.

NRC Report. (2018). Thousands of Children out of school, June 2018. Retrieved from https://reliefweb.int/report/cameroon/thousands-out-school

Roxas, K. (2011). Creating Communities-Working with Refugee Students in Classrooms. Democracy \& Education, 19(2), 1-8.

UNHCR Report. (2019). UNHCR Cameroon Factsheet, May 2019. Retrieved from https://data2.unhcr.org/en/documents/details/69939

UNICEF Report. (2019). More than 855, 000 children remain out of school in South-West and North-West $\begin{array}{lllll}\text { Cameroon, } & 5 & \text { November } & 2019 . & \text { Retrieved }\end{array}$ https://www.unicef.org/press-releases/more-855000-children-remain-out

Windle, J., \& Miller, J. (2012). Appoaches to teaching low literacy refugee-background Students. Australian Journal of Language and Literacy, 35(3), 317-333.

\section{Copyrights}

Copyright for this article is retained by the author(s), with first publication rights granted to the journal.

This is an open-access article distributed under the terms and conditions of the Creative Commons Attribution license (http://creativecommons.org/licenses/by/4.0/). 